\title{
Kreativitas Pengembangan Produk Lampu Meja Dari Limbah Botol Kaca Dengan Metode Upcycling
}

\author{
Awang Eka Novia Rizali, Elda Franzia Jasjfi, Ariani, Erick Teguh Leksono \\ Fakultas Seni Rupa dan Desain, Universitas Trisakti \\ email: elda@trisakti.ac.id
}

\author{
Received: 13 August 2021; Revised: 02 October 2021; Accepted: 26 December 2021 \\ DOI: http://dx.doi.org/10.37905/aksara.8.1.43-54.2022
}

\begin{abstract}
Abstrak
Botol bekas berbahan dasar kaca merupakan limbah yang dihasilkan dari penggunaan bahan makanan seperti kecap, saus, dan minuman. Untuk memperpanjang nilai guna limbah botol kaca, perlu dilakukan pengembangan bentuk produk melalui metode upcycling sehingga dapat memperpanjang usia guna limbah botol kaca yaitu dengan memanfaatkan limbah botol kaca tersebut menjadi lampu meja melalui pelatihan kepada masyarakat khususnya generasi muda. Pelatihan untuk pengembangan bentuk lampu meja dari limbah botol kaca ini dilakukan melalui kegiatan Pengabdian kepada Masyarakat dari Fakultas Seni Rupa dan Desain Universitas Trisakti dengan sasaran masyarakat Kelurahan Kebon Baru, Kecamatan Tebet, Jakarta Selatan. Tujuannya adalah untuk meningkatkan kreativitas dan produktivitas masyarakat serta meningkatkan peluang pendapatan masyarakat di masa pandemi COVID-19 ini. Hasil dari pelatihan ini adalah pengembangan bentuk produk lampu meja berupa 3 model lampu meja dari limbah botol kaca dapat dibuat oleh masyarakat sasaran.
\end{abstract}

Kata Kunci: pengembangan produk, lampu meja, pemanfaatan limbah, upcycling, botol kaca

\begin{abstract}
The used glass bottle is a common wasted product from consumer goods such as soy sauce, tomato sauce, and drinks. Product development with upcycling method is needed to lengthen the glass bottle's time use. The upcycled product is a desk lamp that using glass bottle waste. The Community Service of Faculty of Art and Design was held to youth from Kelurahan Kebon Baru, Kecamatan Tebet, South Jakarta. It was aimed to train the development process of desk lamp from glass bottle waste. The training objective is to enhance the people's creativity and productivity to broaden the opportunity in this current COVID-19 pandemic era. The result is the product development of 3 models of desk lamp from glass bottle waste made by society.
\end{abstract}

Keywords: creativity, product development, desk lamp, upcycling, glass bottle

\section{PENDAHULUAN}

Kreativitas merupakan kemampuan manusia untuk mendapatkan alternatif dalam pemecahan masalah. Melalui kreativitas, manusia tidak terpaku dalam menghadapi masalah yang ada dan mampu mencari kemungkinan-kemungkinan lain yang bersifat membangun dan solutif. Dalam kondisi pandemi COVID-19 ini, kreativitas diperlukan untuk menghadapi kesulitan ekonomi dengan kondisi di mana masyarakat harus lebih banyak berdiam di rumah dan terbatas ruang geraknya di luar rumah. Kesulitan ekonomi yang dihadapi oleh masyarakat di kota besar dalam keterbatasan gerak yang dihadapi oleh masyarakat ini membuat masyarakat khususnya usia produktif perlu dikembangkan wawasan dan keterampilannya untuk mendapatkan sumber pemasukan tambahan dan membantu meningkatkan pendapatan keluarga.

Limbah botol kaca merupakan limbah yang banyak terdapat di kota-kota besar dan wilayah pinggiran kota. Limbah botol kaca ini merupakan wadah bekas pakai dari 
bahan makanan dan minuman, seperti kecap dan saus yang banyak digunakan oleh pedagang makanan kaki lima, serta beberapa jenis minuman. Botol-botol kaca ini belum banyak dimanfaatkan sehingga menjadi limbah yang hanya dikumpulkan oleh penampung dalam proses pembuangannya. Untuk itu dalam upaya mengurangi limbah di kota besar, perlu dipikirkan berbagai cara mengurangi limbah, antara lain dengan memperpanjang waktu guna sebuah materi limbah, termasuk dalam hal ini adalah botol kaca.

Salah satu bentuk kreativitas dalam pengembangan produk dikenal sebagai upcycling (berasal dari kata upcycle). Metode upcycling merupakan salah satu bentuk pemanfaatan limbah daur ulang sebagai upaya mengurangi limbah yang menumpuk dari hasil konsumsi manusia. Upcycle berbeda dari istilah recycle yang lebih populer saat ini. Dalam proses recycle, material sampah mengalami perubahan bentuk untuk dihancurkan dan dilebur menjadi bahan baku siap pakai, sedangkan pada upcycle lebih membutuhkan kreativitas untuk memfungsikan ulang limbah yang tidak terpakai menjadi produk dengan fungsi baru yang memiliki peningkatan nilai estetis dan fungsinya. Adanya peningkatan nilai estetis dan fungsi tersebut membuka peluang bagi produk kreativitas tersebut untuk meningkatkan nilai jual dan menjadi sumber penghasilan bagi masyarakat.

Masyarakat di Kelurahan Kebon Baru, Kecamatan Tebet, Jakarta Selatan, termasuk kelompok masyarakat yang terdampak oleh kesulitan ekonomi akibat pandemi COVID-19 ini. Berlokasi di tengah kota Jakarta, generasi muda di Kelurahan Kebon Baru, Kecamatan Tebet, Jakarta Selatan memiliki akses ke pengumpul limbah botol kaca, selain juga memiliki botol-botol kaca tersebut sebagai bekas pakai di rumah tangga. Di samping itu lokasi yang berada di tengah kota memudahkan masyarakat sasaran untuk mengakses bahan dan alat pendukung yang dibutuhkan. Generasi muda berada dalam usia produktif ini memiliki sumber daya tubuh dan pikiran yang dapat dikembangkan sebesar-besarnya, namun masih membutuhkan bimbingan dalam wawasan kreativitas dan pengetahuan khususnya pengetahuan dasar desain untuk menghasilkan produk upcycle yang menarik dan berdaya guna.

Berdasarkan latar belakang tersebut maka dalam kegiatan Pengabdian kepada Masyarakat yang dilakukan oleh Fakultas Seni Rupa dan Desain kepada masyarakat sasaran yaitu warga Asem Baris Gang 3, RT 03/RW 05, Kelurahan Kebon Baru, Kecamatan Tebet, Jakarta Selatan dilakukan upaya pelatihan untuk mengembangkan kreativitas dan keterampilan masyarakat sasaran dalam mengolah limbah botol kaca menjadi lampu meja. Pelatihan ini diharapkan dapat memberikan keterampilan tambahan bagi masyarakat sasaran sehingga dapat menjadi modalitas tambahan dalam peningkatan taraf hidupnya. Dalam pelatihan ini dilakukan pengembangan bentuk produk lampu meja dengan menggunakan bahan utama limbah botol kaca dan material kayu dengan metode upcycling untuk menghasilkan model-model produk lampu meja yang dapat digunakan dan dapat dijual untuk meningkatkan peluang menambah penghasilan masyarakat yang terdampak pandemi COVID-19 ini.

\section{METODE PENELITIAN}

Metode upcycling adalah metode pemanfaatan limbah daur ulang secara maksimal untuk peningkatan nilai produk dengan pendekatan konsep regenerasi produk (Utomo, Kusumarini, \& S, 2021). Konsep upcycle bertujuan untuk meningkatkan nilai estetika 
maupun nilai ekonomi pada suatu produk dengan tampilan yang baru dan berbeda dari sebelumnya (Hanifah, 2018). Metode upcycling merupakan bagian dari upaya pengurangan limbah dengan menambah usia penggunaan produk sehingga menunda produk itu menjadi limbah yang terbuang. Metode ini juga mengurangi penggunaan material baru sebagai bagian dari konsep sustainable development. Metode upcycling yang dilakukan secara rumahan akan menggunakan lebih sedikit energi terbuang dibandingkan dengan upcycling yang dilakukan dalam lingkup industri (Sung, 2015).

Pelatihan dilakukan dengan metode praktik secara langsung teknis pembuatan produk lampu meja dari limbah botol kaca. Proses pelatihan dilaksanakan dalam 3 (tiga) tahap yaitu (1) Tahap pengenalan material dan teknik, (2) Tahap produksi dan pengembangan bentuk lampu meja, (3) Tahap evaluasi. Pada tahap pengenalan material dan teknologi, instruktur memperkenalkan karakteristik material kaca dari limbah botol kaca yang digunakan dan memaparkan berbagai teknik pemotongan botol kaca untuk mendapatkan ukuran dan bentuk yang diinginkan. Pada tahap kedua yaitu tahap produksi dan pengembangan bentuk lampu meja, instruktur memperagakan tahap-tahap pembuatan lampu meja dari limbah botol kaca dan berbagai eksplorasi bentuk yang dapat dilakukan. Tahap kedua ini dilanjutkan dengan para peserta pelatihan yang melakukan praktik pembuatan lampu meja. Pada tahap ketiga yaitu tahap evaluasi, instruktur bersama peserta pelatihan mengevaluasi hasil dan kendala yang dihadapi.

\section{HASIL DAN PEMBAHASAN}

Kegiatan Pengabdian kepada Masyarakat dengan judul "Meningkatkan Kreativitas dan Produktivitas Masyarakat dengan Memanfaatkan Botol Bekas Menjadi Produk Bernilai Jual" dilaksanakan oleh tim Fakultas Seni Rupa dan Desain Universitas Trisakti pada tanggal 12 Juni 2021. Program ini merupakan salah satu upaya pengembangan sumber daya manusia dan peningkatan kualitas lingkungan dengan pengurangan limbah yang tidak termanfaatkan dan berada di lingkungan sekitar. Tim pelaksana terdiri dari Dosen, mahasiswa, dan alumni, dengan latar keilmuan Desain Produk, Desain Komunikasi Visual, Desain Interior. Keragaman keilmuan desain tersebut mendukung pemahaman terhadap sifat, karakteristik material, elemen estetis, pengolahan dan pengembangan bentuk yang tepat untuk menghasilkan produk bernilai guna baru yang menarik. Sebagai peserta pelatihan adalah masyarakat warga Asem Baris Gang 3, RT 03/RW 05, Kelurahan Kebon Baru, Kecamatan Tebet, Jakarta Selatan yang berprofesi sebagai buruh bangunan dan tukang ojek online yang mengalami kesulitan ekonomi dan terdampak kondisi pandemi COVID-19 saat ini.

Pelatihan ini berperan untuk mengembangkan wawasan dan kemampuan masyarakat tentang peluang industri kreatif melalui pengembangan desain produk, khususnya dalam hal ini melalui pengembangan ketrampilan dan kreativitas untuk memanfaatkan limbah botol kaca dengan metode upcycling. Penerapan metode upcyling mempertimbangkan faktor-faktor (a) Tipe material, (b) Keawetan, (c) Fungsi, (d) Nilai estetika, dan prinsip-prinsip yang menjadi landasan perancangan yaitu (a) Prinsip penguatan nilai, (b) Prinsip tanpa sisa, (c) Prinsip durabilitas dan lingkungan, (e) Prinsip kontrol biaya, (e) Prinsip estetika masyarakat, yang digunakan dalam menghasilkan kreasi produk baru (Tirtawijaya, Kusumarini, \& Suprobo, 2021). Desain produk secara umum dikenal sebagai proses penggabungan fungsi dan estetika yang memiliki nilai tambah tinggi (RI, 2021). Desain produk menjadi subsektor ekonomi kreatif yang cukup 
penting, dan kreativitas diperlukan untuk lebih mengembangkan desain produk dan menghasilkan nilai tambah bagi produk dan masyarakat.

\section{Pemanfaatan Limbah Botol Kaca}

Limbah botol kaca merupakan jenis sampah yang tidak mudah terurai secara alami. Material kaca tidak dapat terurai secara alami oleh mikroorganisme. Botol kaca membutuhkan waktu 1.000.000 tahun untuk dapat terurai di alam. Berdasarkan data statistik limbah kaca di Indonesia pada tahun 2003-2008 di 26 kota besar menyumbangkan limbah kaca sebesar 0,7 ton per tahun (Suyoto, 2008). Salah satu hasil survey dari Bank Sampah Bandung (BSB) Sabilulungan menunjukkan bahwa ada penumpukan botol kaca sebagai limbah wadah botol minuman karena banyaknya masyarakat yang mengkonsumsi dan masih sangat sedikit masyarakat yang melakukan pengolahan botol-botol kaca tersebut (Nursakti, 2016).

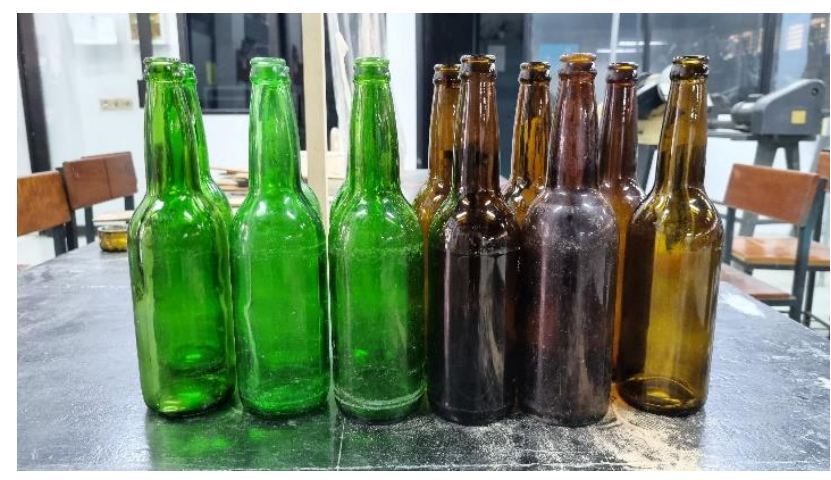

\section{Gambar 1. Limbah Botol Kaca}

Terdapat 3 (tiga) jenis warna kaca yang dapat ditemukan sebagai limbah di Indonesia (Rizali, Jasjfi, Ariani, \& Nugrahadi, 2020; Suhartini, Gunarti, \& Hasan, 2014) yaitu (1) Bening atau tidak berwarna, (2) Hijau, (3) Coklat. Botol bening biasanya digunakan sebagai alat rumah tangga dan terdapat sebagai wadah selai, stoples, dan sebagainya. Botol berwarna hijau banyak digunakan sebagai botol minuman bir, wine, kecap dan saus. Botol berwarna coklat banyak digunakan sebagai botol saus dan minuman ringan. Pada produk upcycling ini yang akan digunakan adalah botol berwarna hijau, coklat dan bening yang merupakan limbah wadah kecap dan saus.

Limbah botol kaca yang ada kemudian dipotong sesuai ukuran yang diinginkan dengan menggunakan alat potong khusus kaca. Ketebalan kaca pada limbah botol ini tidak sama rata, ada yang lebih tipis dan ada yang lebih tebal. Dalam pelaksanaannya, saat menggunakan alat potong beberapa kali botol tidak dapat langsung terputus, sehingga kemudian bagian garis bekas potong dipanaskan di atas api lilin secara mengelilingi mengikuti garis pada botol, kemudian dicelupkan ke air dingin sehingga botol kemudian terpotong. Tahap selanjutnya adalah merapikan bekas potongan tersebut dengan menggunakan amplas sehingga bekas potongan menjadi rapi. 


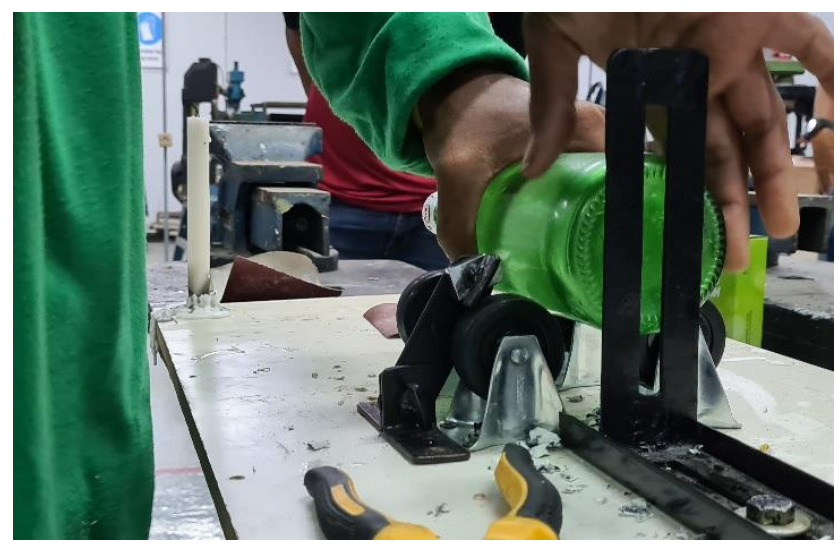

Gambar 2. Proses Pemotongan Botol Kaca

Pemotongan dilakukan pada bagian badan botol yang memiliki diameter lebih besar daripada bagian leher botol. Diameter yang lebih besar ini dibutuhkan untuk ruang tempat lampu dan penampang lampu diletakkan. Botol dapat dipotong secara merata maupun secara diagonal, sesuai kreativitas peserta.

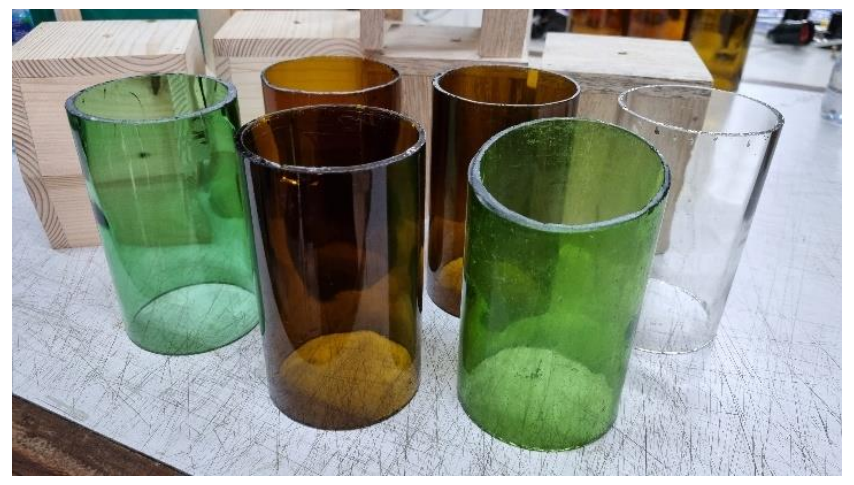

Gambar 3. Botol Kaca Dipotong Sesuai Ukuran yang Diinginkan

Untuk bagian penampang lampu meja digunakan bahan kayu dari peti kemas yang menggunakan jenis kayu alba dan kayu pinus (jati belanda). Jenis kayu pinus lokal Indonesia yang banyak digunakan pada peti kemas berwarna putih kekuningan. Kayu peti kemas merupakan material yang banyak digunakan dalam pengembangan produk industri kreatif, karena material kayu ini dapat mudah didapatkan sebagai limbah kemasan industri, mudah diolah dan memiliki warna alami. 


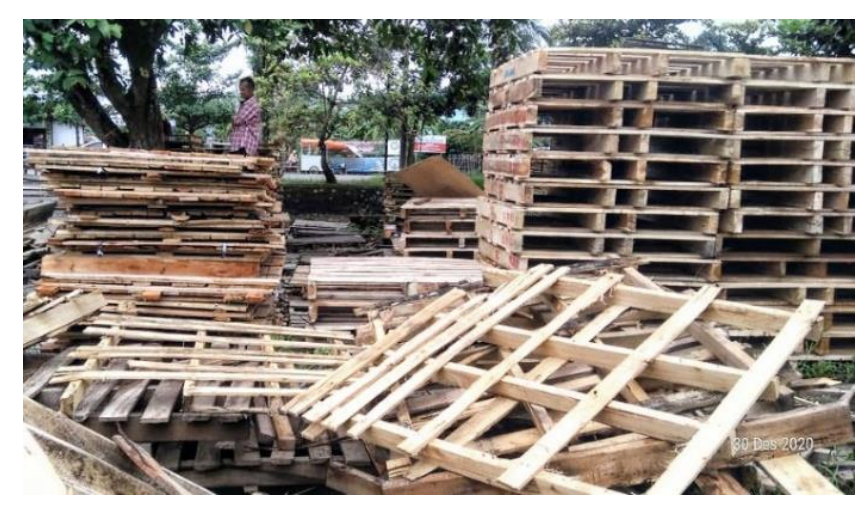

Gambar 4. Limbah Kayu Peti Kemas

Material kayu dari peti kemas memiliki ukuran standar dalam bentuk potonganpotongan kayu, dengan ketebalan 1,5-2 cm dan lebar bilah 7-10 cm. Panjang papan relatif sama yaitu $120 \mathrm{~cm}$ (Safitri \& Rachmat, 2016).

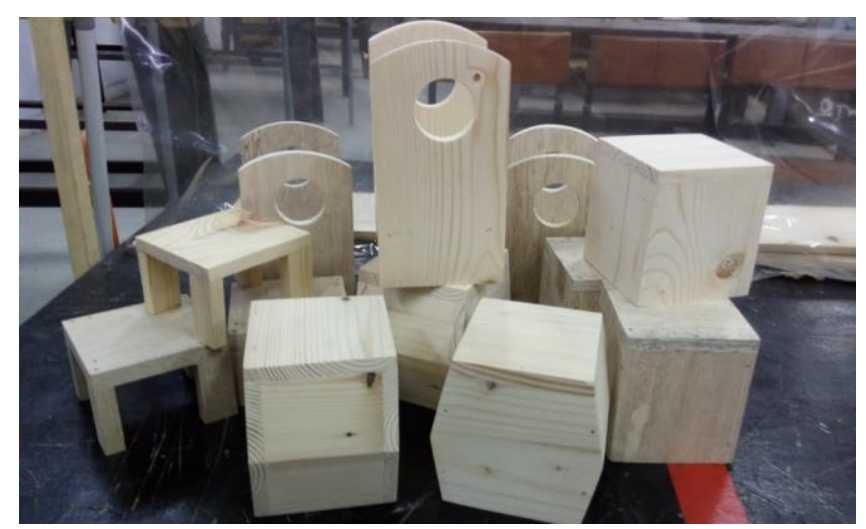

Gambar 5. Material Kayu Penampang Lampu Meja

Material kayu dalam bentuk papan tersebut kemudian dipotong sesuai dengan rancangan penampang lampu meja, yaitu dalam berbagai alternatif bentuk seperti kubus tertutup, bentuk bangku, dan bentuk sekat samping terbuka. Karakteristik material kayu dari peti kemas ini adalah serat dan warna alami kayu, sehingga untuk menampilkan estetika material tersebut dapat dengan hanya dihaluskan dengan amplas. Selain itu material kayu peti kemas ini juga memiliki mudah diolah dan ketahanan yang baik. Kayu peti kemas dirakit sesuai bentuk yang diinginkan, kemudian dibuat lubang menggunakan bor tembus yang berfungsi sebagai lubang kabel.

\section{Proses Pelatihan}

Setiap peserta mendapatkan bahan dan alat yang terdiri dari botol kaca, kayu peti kemas, dan alat listrik digunakan sebagai komponen pendukung untuk membuat lampu meja yang terdiri dari bohlam 5 watt/pijar warna, fitting tempel, kabel, switch gantung, dan steker. 


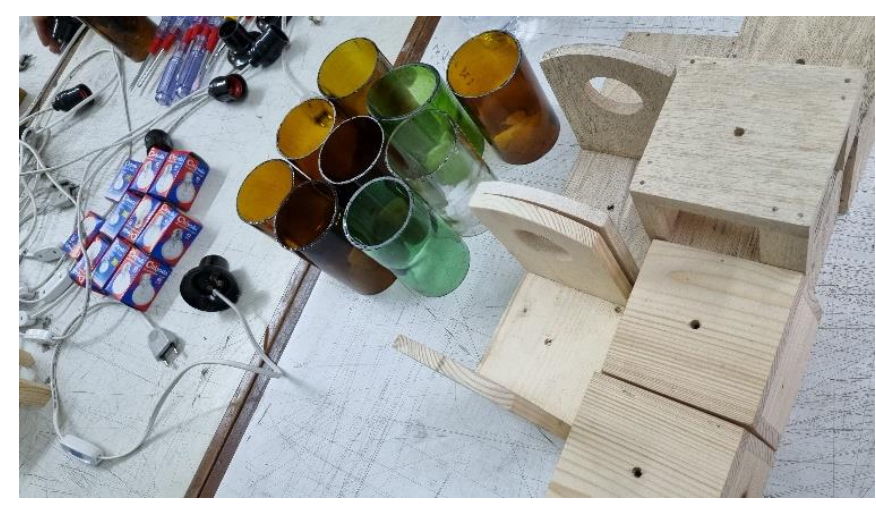

Gambar 6. Alat dan Bahan Untuk Pelatihan

Proses pelatihan dilaksanakan dalam 3 (tiga) tahap yaitu (1) Tahap pengenalan material dan teknik, (2) Tahap produksi dan pengembangan bentuk lampu meja, (3) Tahap evaluasi. Tahap pertama merupakan tahapan yang penting sebagai landasan program. Instruktur mengawali dengan menjelaskan maksud dan tujuan pelatihan dalam program Pengabdian kepada Masyarakat ini serta manfaat yang diharapkan didapatkan oleh peserta pelatihan, dilanjutkan dengan penjelasan tentang karakteristik material yang digunakan, yaitu limbah botol kaca dan material kayu peti kemas sebagai pendukung.

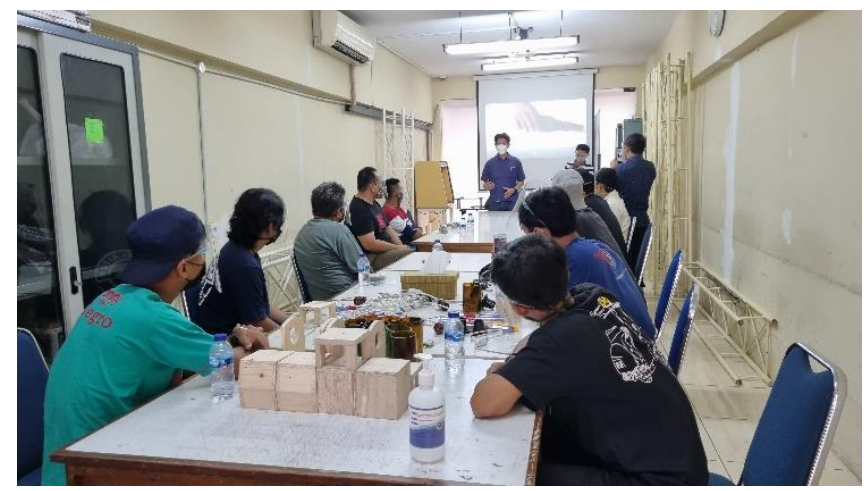

Gambar 7. Tahap Pengenalan Material dan Teknik

Pada tahap ini juga dijelaskan mengenai beragam teknik dalam pemotongan botol kaca agar dapat menghasilkan potongan botol yang halus dengan proses yang dapat dilakukan oleh peserta pelatihan dengan mudah. Selain itu juga diperlihatkan berbagai produk yang dapat dihasilkan dan dikembangkan dengan memanfaatkan limbah botol kaca, hal ini bertujuan agar para peserta pelatihan memiliki wawasan kreativitas dan ide untuk menghasilkan berbagai pengembangan produk yang dapat dikembangkan selanjutnya.

Tahap kedua merupakan tahap produksi dan pengembangan bentuk lampu meja. Pada tahap ini instruktur menjelaskan dan memperagakan tahap-tahap pembuatan lampu meja dari limbah botol kaca dan berbagai eksplorasi bentuk yang dapat dilakukan. Setelah penjelasan dilakukan dan demo cara memotong botol kaca diperlihatkan, para peserta 
pelatihan diminta membuat secara individual dengan memanfaatkan alat dan bahan yang telah diterima.

Untuk membuat dudukan struktur pada lampu meja, kayu peti kemas bekas dipotong sesuai bentuk dan ukuran yang dibuat dengan menggunakan alat gergaji. Setelah dipotong, bekas potongan dirapikan dengan menggunakan amplas halus dan kasar. Kayu peti kemas bekas yang sudah dibentuk kemudian dibor tembus untuk membuat lubang kabel berdasarkan pola yang sudah disiapkan sebelumnya.

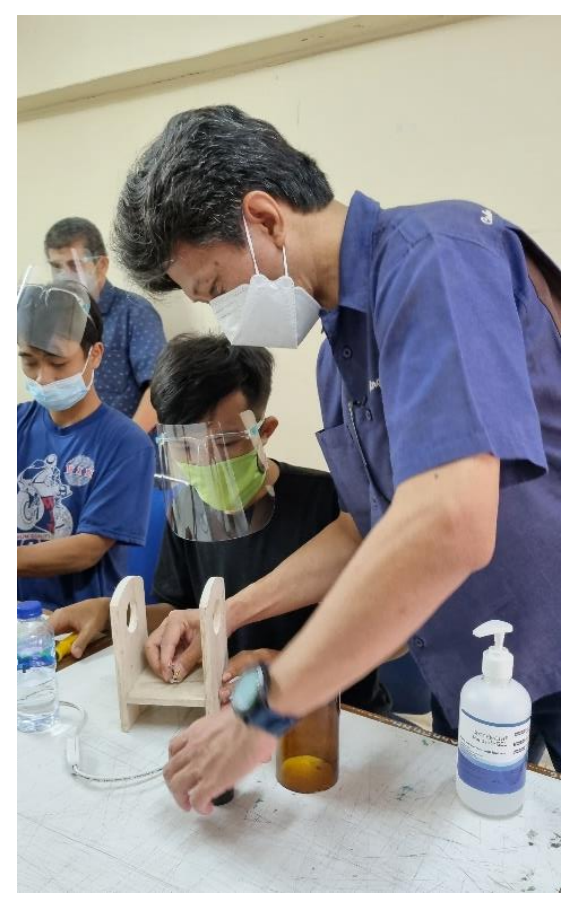

Gambar 8. Tahap Produksi

Pada tahap ini para peserta melakukan perakitan material kayu peti kemas dan peralatan listrik pendukung. Dalam tahap ini ditemukan berbagai ide pengembangan bentuk lampu meja dengan variasi bentuk-bentuk potongan kayu untuk bagian penampang lampu. Kreativitas dibutuhkan dalam tahapan ini, untuk menghasilkan berbagai kemungkinan pengembangan bentuk lampu meja.

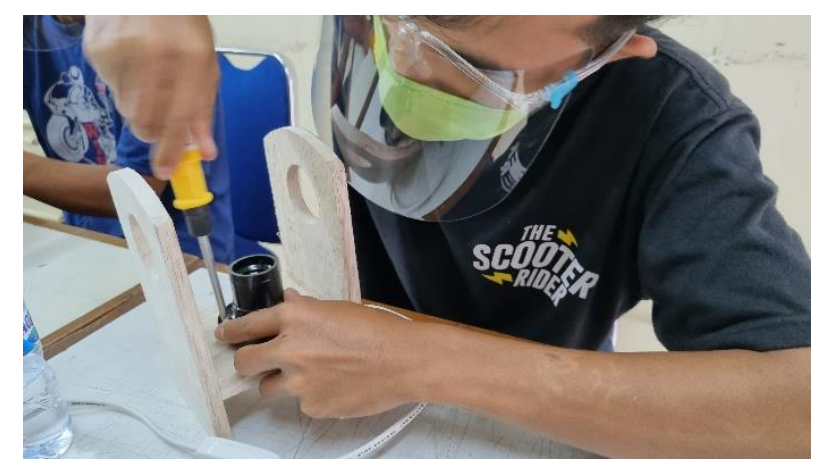

Gambar 9. Proses Instalasi Lampu 
Para peserta pelatihan melakukan proses instalasi lampu dengan memasang komponen alat listrik pendukung, merakit kabel dan menyambung ke fiting dan switch hingga ke steker. Setelah komponen-komponen tersebut terpasang dilakukan pengetesan untuk memastikan lampu sudah dapat menyala. Bagian penampang yang telah dipasang komponen lampu kemudian digabungkan dengan botol kaca yang telah dipotong dalam tahap persiapan sebelumnya.

Tahap evaluasi dilakukan oleh para peserta dan instruktur setelah pelatihan selesai dilakukan. Melalui tahap evaluasi ini, para peserta membandingkan hasil produk lampu meja antara satu dengan yang lain, dan melakukan evaluasi proses, kekurangan dan kesalahan yang dilakukan selama pelatihan. Meskipun tidak ditemukan kegagalan hasil, beberapa peserta menemui kesulitan dalam tahap pemotongan botol kaca dan proses perakitan lampu. Hal ini menjadi perhatian para instruktur dan dapat diatasi dengan melakukan pembimbingan secara intensif pada tahap tersebut.

\section{Hasil Pelatihan}

Melalui proses pelatihan ini, masing-masing peserta dapat menghasilkan 1 (satu) buah produk lampu meja dengan 3 (tiga) variasi pengembangan bentuk yaitu Model 1 dengan dudukan model bangku, Model 2 dengan dudukan kayu bersekat samping, Model 3 dengan dudukan berbentuk kubus atau trapesium.

\section{Model 1}

Model 1 adalah lampu meja dengan dudukan kayu model bangku. Bagian penampang lampu pada Model 1 terdiri dari bagian atas yang berbentuk persegi empat sama sisi dan bagian kaki yang terdiri dari 4 (empat) bilah persegi panjang berukuran kecil.

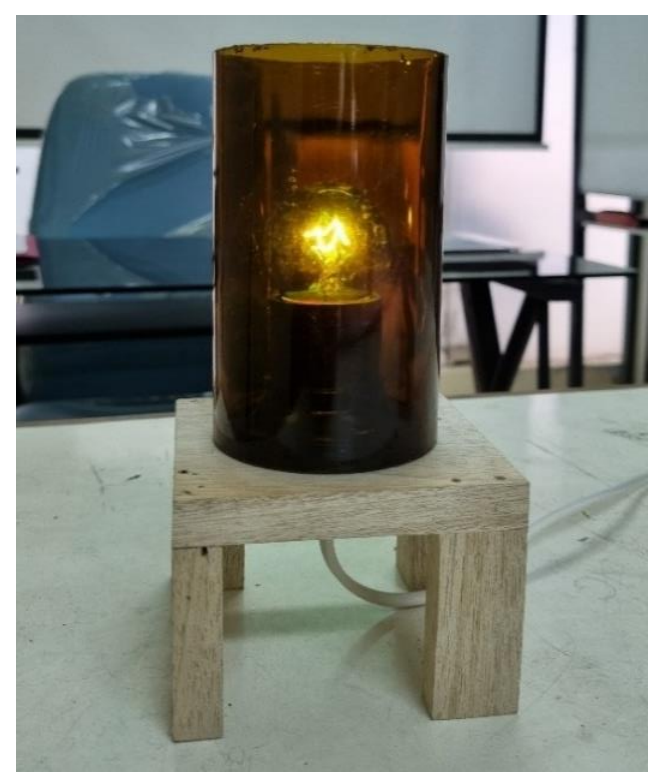

Gambar 10. Lampu Meja dengan Dudukan Kayu Model Bangku

Bentuk bagian penampang ini menghasilkan ruang di bawah bagian lampu yang berfungsi sebagai ruang untuk kabel. Model 1 merupakan lampu meja dengan bentuk 
penampang yang paling sederhana. Variasi bentuk pada lampu meja dengan Model 1 dapat dihasilkan dengan membuat perbedaan panjang dan lebar bagian atas dan perbedaan tinggi bagian kaki.

\section{Model 2}

Model 2 adalah lampu meja dengan dudukan kayu bersekat samping. Bagian penampang pada lampu Model 2 terdiri dari bagian alas yang berbentuk persegi empat sama sisi dan 2 (dua) buah bilah untuk bagian sisi kanan dan kiri yang berbentuk persegi panjang dengan salah satu sisi dipotong berbentuk melengkung. Di bagian atas bilah kayu berbentuk persegi panjang tersebut dibuat lubang dengan ukuran yang cukup besar agar cahaya lampu dapat terlihat melalui lubang tersebut.

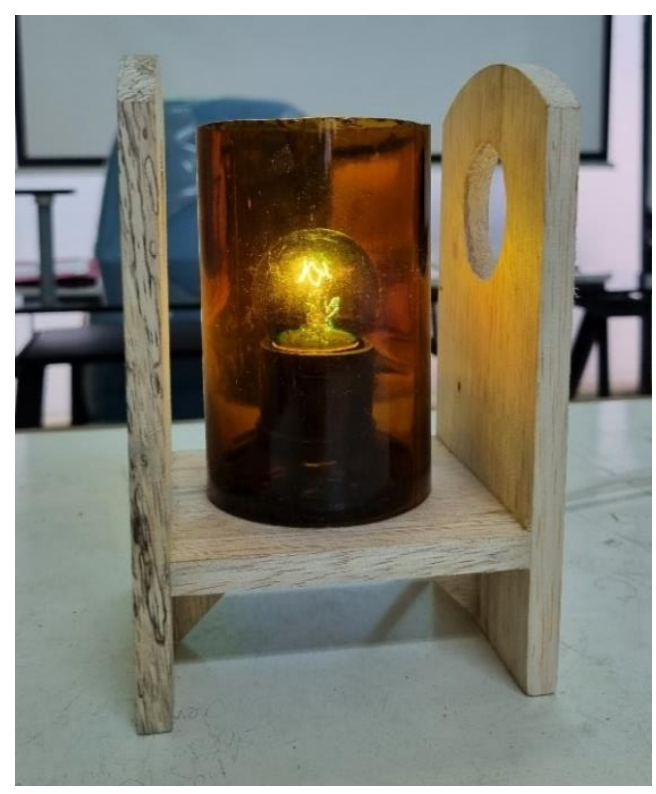

Gambar 11. Lampu Meja dengan Dudukan Kayu Bersekat Samping

Bentuk bagian penampang ini menghasilkan bentuk lampu yang lebih estetik dengan adanya elemen lengkung dan lubang bulat pada bagian sisi kanan dan kiri lampu meja. Bagian sisi tersebut mengurangi cahaya lampu namun akan menghasilkan cahaya dan bayang yang membias pada sisi kanan dan kiri. Pada bagian bawah lampu serupa dengan Model 1, terdapat ruang di bawah lampu untuk kabel namun dengan perbedaan bentuk sisi kanan dan kiri yang juga tertutup pada bagian bawah.

\section{Model 3}

Model 3 adalah lampu meja dengan dudukan kayu berbentuk kubus/trapesium. Model 3 terdiri dari Model 3a yaitu lampu meja dengan dudukan kayu berbentuk kubus dan Model $3 \mathrm{~b}$ dengan dudukan kayu berbentuk trapesium. Bagian penampang pada lampu Model 3a berbentuk kubus yang terdiri dari 6 (enam) buah bilah kayu segi empat sama sisi, sedangkan pada Model 3b terdiri dari 2 (dua) buah bilah kayu segi empat sama sisi untuk bagian atas dan bawah, 2 (dua) buah bilah kayu berbentuk trapesium dan 4 (empat) buah bilah kayu persegi panjang ukuran kecil untuk penutup bagian samping kanan dan kiri. 


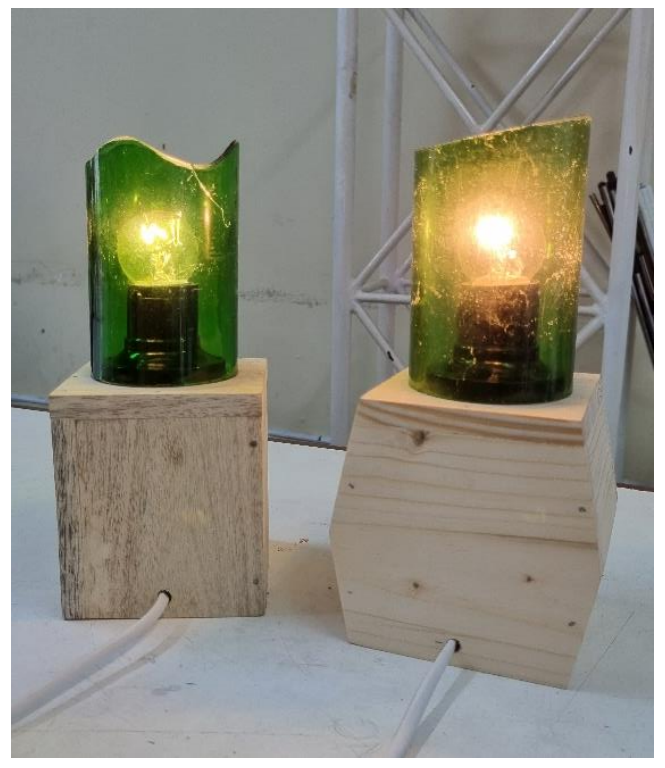

Gambar 12. Lampu Meja dengan Dudukan Kayu Berbentuk Kubus/Trapesium

Bentuk bagian penampang ini menghasilkan bentuk lampu yang lebih kokoh dengan perbandingan tinggi yang sama antara bagian lampu dengan bagian penampang. Bentuk penampang yang tertutup tersebut menyebabkan perlu dibuat lubang pada salah satu sisi kubus/trapesium sebagai jalan untuk kabel, namun hal tersebut tidak mengurangi estetik dari lampu Model 3 ini. Untuk menambah estetika lampu meja, dapat dibuat variasi ukuran panjang dan lebar bagian penampang, dan variasi potongan botol kaca yang digunakan.

\section{KESIMPULAN}

Kegiatan pelatihan dalam program Pengabdian kepada Masyarakat berjalan dengan baik dalam memenuhi tujuan dan sasaran pelatihan. Pelatihan ini menghasilkan pengembangan bentuk produk lampu meja berupa 3 (tiga) model lampu meja dari limbah botol kaca yang dibuat oleh masyarakat sasaran. Ketiga bentuk produk lampu meja menggunakan metode upcycling untuk menghasilkan lampu meja yang estetis dengan menggunakan material yang sederhana dari limbah. Dari bahan baku yang sama dan dengan menggunakan peralatan yang sama, para peserta mengembangkan kreativitas untuk menghasilkan alas lampu dengan berbagai bentuk dan potongan botol kaca yang disesuaikan dengan alas lampu dari material kayu tersebut.

Berdasarkan hasil evaluasi hasil pelatihan, para peserta pelatihan dapat menghasilkan kreasi lampu dengan mengikuti panduan teknis dari para instruktur. Beberapa kendala yang ditemukan merupakan kendala teknis yang dapat diatasi dengan bimbingan dan arahan dari para instruktur. Para peserta merasakan manfaat dari pelatihan ini sebagai kegiatan yang menarik dan menjadi modal untuk menghasilkan produkproduk upcycle dengan memanfaatkan material limbah yang dapat dengan mudah diperoleh di lingkungan sekitarnya. Kreativitas dan hasil pengembangan produk ini diharapkan dapat menambah peluang mendapatkan sumber pendapatan tambahan di tengah kondisi pandemi ini. 


\section{REFERENSI}

Hanifah, H. (2018). Konsep Upcycle Sebagai Alternatif Solusi Pemanfaatan Limbah Kebaya Lama. In e-proceeding of Art \& Design (Vol. 5, pp. 2317-2334). Retrieved from https://openlibrary.telkomuniversity.ac.id/pustaka/145653/konsep-upcyclesebagai-alternatif-solusi-pemanfaatan-limbah-kebaya-lama.html

Nursakti, A. P. (2016). Memanfaatkan Sampah Botol Kaca Sebagai Bandul Aksesoris. In e-proceeding of Art \& Design (pp. 206-218). Retrieved from https://openlibrary.telkomuniversity.ac.id

RI, K. (2021). Pentingnya Subsektor Desain Produk dalam Ekonomi Kreatif. Retrieved from https://kemenparekraf.go.id/ragam-ekonomi-kreatif/Pentingnya-SubsektorDesain-Produk-dalam-Ekonomi-Kreatif-

Rizali, A. E. N., Jasjfi, E. F., Ariani, A., \& Nugrahadi, G. (2020). Pemanfaatan Limbah Botol Kaca Menjadi Lampu Dinding. Jurnal Abdi Masyarakat Indonesia, 2(2), 7989. https://doi.org/10.25105/jamin.v2i2.7483

Safitri, R., \& Rachmat, G. (2016). Studi Kelayakan Kayu Bekas Landasan Peti Kemas Sebagai Elemen Interior Lepas. ATRAT: Visual Art \& Design Journal, 4(3), 243252. Retrieved from https://jurnal.isbi.ac.id/index.php/atrat/article/view/364/310

Suhartini, A., Gunarti, A. S. S., \& Hasan, A. (2014). Pengaruh Penambahan Tumbukan Limbah Botol Kaca Sebagai Bahan Substitusi Agregat Halus Terhadap Kuat Tekan dan Kuat Lentur Beton. Bentang, Jurnal Teoritis Dan Terapan Bidang Rekayasa Sipil, 2(1), 66-80. $\quad$ Retrieved from http://jurnal.unismabekasi.ac.id/index.php/bentang/article/view/363

Sung, K. (2015). A Review on Upcycling: Current Body of Literature, Knowledge Gaps and a Way Forward - IRep. In 17th International Conference on Environmental, Cultural, Economic and Social Sustainability. Venice. Retrieved from http://irep.ntu.ac.uk/id/eprint/12706/

Suyoto, B. (2008). Fenomena Gerakan Mengolah Sampah. Jakarta: PT Prima Infosarana Media.

Tirtawijaya, G. A., Kusumarini, Y., \& Suprobo, F. P. (2021). Perancangan Furnitur Berbasis Upcycling Waste Material Batu Alam. Productum: Jurnal Desain Produk (Pengetahuan Dan Perancangan Produk), 4(2), 87-94. https://doi.org/https://doi.org/10.24821/productum.v4i2.4143

Utomo, T. N. P., Kusumarini, Y., \& S, S. E. (2021). Eksplorasi Kreativitas Desain Melalui Konsep Upcycle Material Produk Furnitur Paska Pakai. Productum: Jurnal Desain Produk (Pengetahuan Dan Perancangan Produk), 4(1), 59-66. https://doi.org/10.24821/productum.v4i1.4106 